\title{
Interview with Mieke Bal
}

Catriona McAra and Anna Kérchy

AQ1 AQ2

Catriona McAra and Anna Kérchy: We would like to start by asking about your own feminist stance, and where you see the feminist project today? Griselda Pollock was convinced by the feminism of your intermedial arguments in your book Reading 'Rembrandt': Beyond the Word/Image Opposition (1991) almost 30 years ago. From Rembrandt to Proust, and from Louise Bourgeois to Bernini, narratives of the female body have always seemed to have been a preoccupation for you. How much was your pioneering crossing of disciplinary borders and move from narratology to visual rhetoric informed by a feminist agenda, a strategic rebellion against gender-biased criticism?

Mieke Bal: It is always difficult to answer such questions about past decisions. Or, rather 'inflections', because they never meant a complete turn of shift. Many such turns are motivated by multiple, often half-conscious causes. There is almost always a merging of intellectual and biographical motivations. My first memory of my incipient feminism goes back to a remark that passed between my parents when I was four years old. I remember that I overheard my father saying, lovingly:'I am so happy to have daughters; they are such wonderful home-makers.' All I know with certainty is the mental headshake I made in response to the sentiment that the good man had expressed: no way! I can still feel the headshake in my neck, even though it was only a mental one. I remember that rejection as clearly as if it was yesterday. Then, when I published my book Narratologie (in French, on French novels), a review by a well-known feminist critic pointed out that it was a feminist book - something I had not been aware of at all. For me it was an earnest structuralist attempt to think through the logic of narrative. But yes, looking back, she was right. So, it must have been a personality feature rather than a consciously decided-on political choice. It seems natural to me. And so is 'rebellion'. My parents told me that I was always protesting and nagging, and I suppose something similar happened with that border crossing. I didn't see any borders, so I didn't consciously cross any.

But there is another personality feature involved in my moving from narratology across that, for me, invisible border to the visual. That is a combination of limitless curiosity and easily getting bored with doing what I already know how to do. An intellectual restlessness; I call it a tendency to look around the corner. This happened earlier, for example, when I was challenged by theory-hostile colleagues to try out my theory of narrative on another body of texts than modern European novels to assess how general its validity could be taken to be. This - along with an anecdotal encounter - brought me to the Hebrew Bible. But once I knew how to do feminist literary analyses of biblical narratives, and had inflected the theory 
a bit in view of cultural, historical but especially gender differences, in particular, including the negative questions of agency: who can speak, see, act; but also, who cannot?, I got itchy again. And then a Rembrandt etching I had found for my book cover brought me to the visual domain.

The final step so far has been to integrate analysis with making in order to get to a deeper and more contemporary understanding of (inter)cultural issues. My filmmaking is not at all a 'career shift' as many have assumed, but a form of methodological enrichment that made better use of the creativity I also had in me. But then just this year another thing happened. With the invitation from the Munch Museum in Oslo to curate an exhibition and integrate our Madame B into it, I experienced the joy of curating (already tasted a bit earlier but never really pursued), and that felt like a homecoming. And, of course, in the exhibition and the book I wrote for it, the feminism is still going strong. But it was almost a shock to feel the profound joy of being so close to, and so durationally in the company of great paintings; to select, make sense of and design the hanging of those masterpieces, and feel responsible to make sense of the combination of the Munchs with our humble videos.

Catriona McAra and Anna Kérchy: In his 1996 introduction to /cons-Texts-lconotexts, Peter Wagner called you (along with Norman Bryson and Barbara Stafford) the 'enlightened singers or prophets in the desert' to whose challenging enquiries art history in America and Britain has yet to respond. Has a dialogue been established between your work and art history 20 during the past two decades?

Mieke Bal: Yes, I think we were really not alone; perhaps we just changed the tone and accents a bit, since we came out of different types of training. Already in 1981, Griselda Pollock, for example, published, with Rozsika Parker, Old Mistresses, when I was still doing 'only' literature. That eye-opening book, with its brilliantly tongue-in-cheek title, opened feminism for art history. That was a milestone. Pollock has never relented since, and I deeply admire the way she stands by her convictions. Since then, the initial resistance by many but never all art historians has faded a bit. In all disciplines there will always be conservative scholars who reject 'impurity'. But more interestingly, even progressive scholars can stumble over certain things they consider damaging to a discipline, or even to an interdiscipline. For example, my dear friend W. J.T. Mitchell, whose work I respect and admire enormously, and who, I think, respects mine as well, could not help himself decrying 'the tendency to "linguistify" art history led by Norman Bryson and Mieke Bal in the 1980s' (Image Science 2015: 118). Confusing semiotics with linguistics is a fundamental error that holds interdisciplinarity back. And this is quite astonishing coming from such a serious scholar who also started out in literary studies and on whose side I have always found myself. Others, ignorant of even the broadest disciplinary divisions, have persistently called me a'linguist'. I consider it bizarre to not know about the traditional and fundamentally broad division between linguistics and literature in all language departments. That comes, perhaps, close to a desert.

There are some paradoxes involved in this question. It is not always disciplinary orthodoxy that hampers a dialogue. Sometimes, prejudices or opinions that are settled and fixated in one's mind close people off from possibilities. And, of course, let's not forget that the time we have to read the work of others is limited. I trust this is what lies behind Mitchell's dismissal of a long article that examined the potential of semiotics for art history, an article that many others even many more conservative art historians have found to be very helpful. Incidentally, this shows the risks of commenting on work unread - a frequent vice. But I can say I have 
learned enormously from leading art historical thinkers and vice versa. My receiving the Distinguished Lifetime Achievement Award for Writing on Art from the CAA [College Art Association] in 2011 can only mean that an opening up and a dialogue have taken place. The same can be stated about several awards from the American Academy of Religion (the equivalent of the (AA) and even from the Biblical Archaeology Society for my Bible work. This must point at a dialogic attitude in those fields that we tend to consider closed. No, not a desert, just a community as conflicted as any community.

I have found that the bones of contention can be something very different from just disciplinary hang-ups. With the Bible, I have realised that my respect for the texts, which appear in the work, was in the end an appeal that was stronger than my areligious attitude and lack of solid Hebrew were repulsive to me. The strange situation is that some people firmly entrenched in art history have more affinity with my work than some'hip' visual culture people. Again, this is due, I think, to my 'first principle', which is close engagement with the images. For people seriously interested in art, this is important. For those who are still fighting the rearguard battle of contesting the distinction between artistic and other images, this engagement with the text, image or other cultural artefact appears reactionary in itself. And some individuals in both art history and visual culture dismiss this as 'formalist'. But that is just because fighting is their mode of action rather than doing the scholarship that might persuade in its own right. I think that attention to details is precious. This is what I got out of my literary training.

Catriona McAra and Anna Kérchy: The notion of 'quotability' has been a recurrent one in your cultural analysis, as a'travelling concept' that is applicable throughout the humanities. Can we understand this in relation to the female body? We are particularly interested in your notion of the theoretical 'navel of the text' as a mode of reading.

Mieke Bal: Cultural artefacts consist of elements taken from what already exists. Just think of language, but also many other things, like forms, shades and tones. Hence, as the French structuralists - Lévi-Strauss as the pioneer, but following Saussure - put forward with their concept of bricolage: the building stones are never new, only what we do with them. Quoting is inevitable. Doing it with critical awareness so as to reframe the quoted elements is a creative method, most notoriously practised by Flaubert. Among those cultural utterances that can be quoted, taken up and reframed, is, of course, the female body, and the male body for that matter (e.g. heroic sculpture). Bodies are also cultural, and the way women's bodies have been put forward as artefacts to engage with and think about was obviously up for discussion when feminism came along again.

What I tried to do with the'navel' in Reading 'Rembrandt' was to bind together an openness for a mode of reading that can go in all directions, that is not limited to linearity (an obsession that can be considered primarily male for more than one reason), yet also keeping a central thought in mind: an awareness that the navel is a bodily thing - a 'scar' - that every human being has. So in that sense navel is non-gendered, while, at the same time, recalling, that in life, the provenance of the human to its mother makes it utterly gendered. It was my way of reminding us that women are not only ineradicable and, hence, cannot be overlooked the way they so often are, but also, if hierarchies are necessary, more, they are more rather than less essential than men. So, it was simultaneously a logical method to overcome strict boundaries and hierarchies and a gender cautionary. With this I attempted to integrate the logic of analysis with a gendered vision without creating a conflict between aesthetic and political thinking. 
Catriona McAra and Anna Kérchy: More recently, you have returned to Gustave Flaubert and the idea that Flaubert was a feminist, particularly in his novel Madame Bovary (1856). Can you tell us about your filmic engagement with his novel, what you have termed 'creative anachronism' as well as your collaboration with Michelle Williams Gamaker?

Mieke Bal: I had been making films with Michelle for years when, on the day of the premiere of our first fictional film, we had that flash that often comes with a bit of a dip when a project of years is finished: 'What do we do now?' For making is addictive. The idea that 'this is it' was not acceptable. That was when I suddenly saw Flaubert, the first object of my academic work, as if he were sitting next to me and winking. Yes, a fiercely feminist writer who was also known to be a misanthrope and difficult with women as a person. It is his text, that masterpiece that he wrote over five years of struggling with language, that for Michelle and me demonstrated that that such struggle can lead to an insight into what for us became 'Emma now'. This is the appeal of capitalism and romantic love that we call, with sociologist Eva Illouz, 'emotional capitalism'. Flaubert's novel is strongly contemporaneous with his own time. And this is what we, in loyalty to his endeavour, sought to do with our Madame B: to place her in our time. Anachronism thus is necessary in order to be historically responsible to a novel that bespeaks its own period. And this requires creative interventions like replacing some scenes that are too specifically anchored in the mid nineteenth century with an equivalent but, of course, very different scenes that are fitting for our own time.

The challenge was to show, audiovisually, Emma and what happened to her - the fatal course of her life due to the enticement to crave that impossible thing, permanent excitement. To make a film that is not the usual historical costume drama that puts viewers at a reassuring distance, but, instead, that invites them in, and to simultaneously facilitate a critical awareness along with compassion and empathy. This was important to us as a broader intervention in traditions of filmmaking, where Hollywoodish tearjerkers tend to be considered radically distinct from experimental 'artistic' films. I think Flaubert walks that fine line between the two perfectly in his novel. We sought to examine to what extent film can do something like walking the fine line as well. This is also the reason why our fictional films consist of features as well as installation pieces. With this combination we have been able to create immersive exhibitions that still maintain the possibility of inviting critical reflection. The current Madame B exhibition in the museum Aboa Vetus \& Ars Nova in Turku, Finland (9 March-28 May 2017) is a good example of this. All of the exhibitions based on this material are different, depending on the space and the vision of curators. That Flaubert is 'present' in these exhibitions, with his contemporaneity critique and quotational style, became especially clear in the exhibition 'Emma \& Edvard: Love in the Time of Loneliness' in the Munch Museum in Oslo (27 January-17 April 2017). The director of collections and exhibitions Jon-Ove Steihaug remarked several times that the exhibition, which I curated myself at his invitation, had demonstrated the possibility of bringing literature into the museum.

The collaboration with Michelle has been a dream come true. With her great creativity and her keen artistic-critical sense, she has been of crucial importance to me in releasing my own creativity. I would have never been able to mobilise without her, or perhaps only a bit with my 'looking around the corner'. We share a feminist commitment, a Flaubertian desire to 'faire beau', to make beauty a tool of persuasion as well as a value in its own right, a total respect for each other's input and last, but not least, the same fast pace, because we are people propelled by creative desire. The collaborative nature of filmmaking has been a key attraction for me. 


\section{Notes on contributor}

Mieke $\mathrm{Bal}$ is a cultural theorist, critic, video artist and occasional curator. She works on gender, migratory culture, psychoanalysis and the critique of capitalism. Her 38 books include a trilogy on political art: Endless Andness (on abstraction), Thinking in Film (on video installation), both 2013, Of What One Cannot Speak (on sculpture, 2010). Her earlier work comes together in A Mieke Bal Reader (2006). In 2016 appeared In Medias Res: Inside Nalini Malani's Shadow Plays (Hatje Cantz), and in Spanish, Tiempos trastornados on the politics of visuality (AKAL, 2016). Her video project Madame B, with Michelle Williams Gamaker, is widely exhibited, in 2017 in Museum Aboa Vetus \& Ars Nova in Turku, and combined with paintings by Edvard Munch in the Munch Museum in Oslo. Her most recent film is Reasonable Doubt, on René Descartes and Queen Kristina (2016). In March 2017 she was appointed Ridder in the Orde van de Nederlandse Leeuw (Knight in the Order of the Netherlands Lion). Website: http://www.miekebal.org.
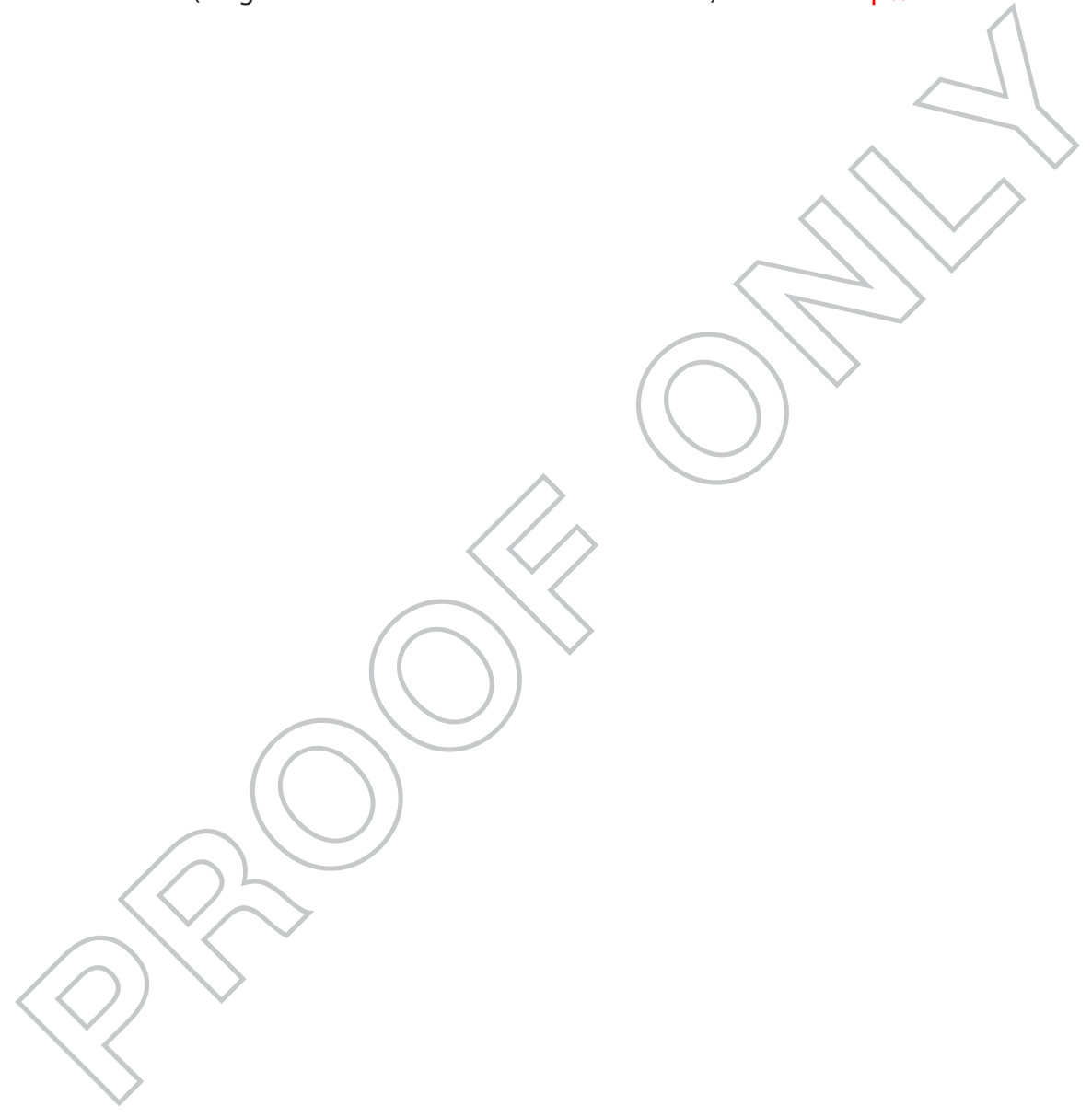